臨床 先端巨大症とBasedow病を合併した 1 例

\begin{tabular}{|c|c|c|c|c|}
\hline \multicolumn{5}{|c|}{ 東京大学医学部第二内科 } \\
\hline 玉岡 & 晃○ & 木野 & 博至 & 野中 \\
\hline 行徳 & 祐一 & 芹沢 & 剛 & 石井 \\
\hline
\end{tabular}

\title{
A COMBINED CASE OF ACROMEGALY AND BASEDOW'S DISEASE
}

Akira TAmaOKA, MD, Hiroyoshi KINo, MD, Yasunobu NonaKa, MD, Yuichi GYotoku, MD, Takashi SerIzAwa, MD and Masao IsHII, MD The Second Department of Internal Medicine, Faculty of Medicine, University of Tokyo

\begin{abstract}
概要 先端巨大症と甲状腺機能六進症との合併例は, 1927年にCushing and Davidoff が報告し て以来，20例以上の報告例があるが，その中で，先端巨大症とBasedow病の合併例は1例しか なく，本例は第 2 例目である，両疾患の合併関して，若干の考察を試みた。症例は23才，女 性. 10年前より易疲労感・腰痛があり，5年前より次第に鼻尖，下顎，手指，足趾などの先端 巨大が生じてきた。 2 年前より発汗増加，1 年前より手指振戦，動悸む出現し，精査治療のた め当科入院、入院時現症では，先端巨大症，皮虚湿潤，手指振戦，頻脈の他，び漫性ゴム様硬

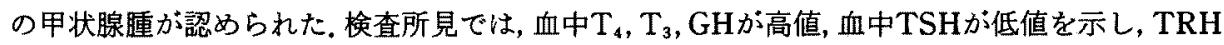
試験に反応せず, thyroid test，LATSは陰性であつたが， microsome testは陽性であり，甲状 腺シンチやェコーでび漫性甲状腺腫が認められた，以上ょり，本例は先端巨大症とBasedow病 の合併例と診断され，甲状腺機能六進症に対してメルカゾールによる治療を行ない, euthyroid の状態となつてから，下垂体腺腫の垔全摘を施行した。この間, 種々の内分泌学的検查を施行 したが，本例における先端巨大症とBasedow病の合併に関しては, Basedow病がGH增加を助 長していた可能性は否定できなかつたが，両疾患の因果関係を積極的に示唆する所見は得られ ず，両疾患の合併は偶然であろうと推測するのが妥当であると考えられた。
\end{abstract}

\begin{abstract}
緒言
先端巨大症の甲状腺機能に関する報告は少ない が, 先端巨大症に招いては, 発汗増加, 基䃈代謝 率の増加がみられ，甲状腺畽は25～50\%に認めら れることが報告されている112)。これらは，成長小 ルモン分泌過剰による症状, または臟器肥大の一 部分症状と考兄られて扣り，実際に血中甲状腺木 ルモンが高值である症例はまれである．今回著者 らは，先端巨大症にBasedow病を合併した症例を 経験したので，これを報告し，両疾患の合併に関 して若干の考察を試みた。
\end{abstract}

\section{症例}

患者：23才，女性，家事手伝い。

[昭和59年 9 月 21 日受稿]
主訴：手指, 足趾などの先端巨大, 発汗過多, 手指振戦, 動悸.

家族歴：父方祖父に糖尿病, 父方祖母に高血 圧, 脐へルニア。

既往歴：8才時肺炎，21才時大腸カタル。

現病歴：1970年（13才時）頃上り易疲労感が あり，5分位の起立で腰痛が生じたという，1975 年から四肢の多毛に気づき，1976年頃から食欲元 進, 体重増加がみられ，次第に鼻尖，下䫟，口唇， 手指，足趾などに先端巨大が生じてきた，1976年 頃から口渴・多领多尿がみられ，情緒不安定とな ク，いらいらすることが多くなつてきた. 同じ頃, 声が低音となつてきたと指摘され，月経も不順に なつてきた. 1978年頃から両側手掌のしびれ感， 全身の発汗增加, 眼䀫浮腫がみられ, 不眠㑯向が 
表 1. 一般娭查所見

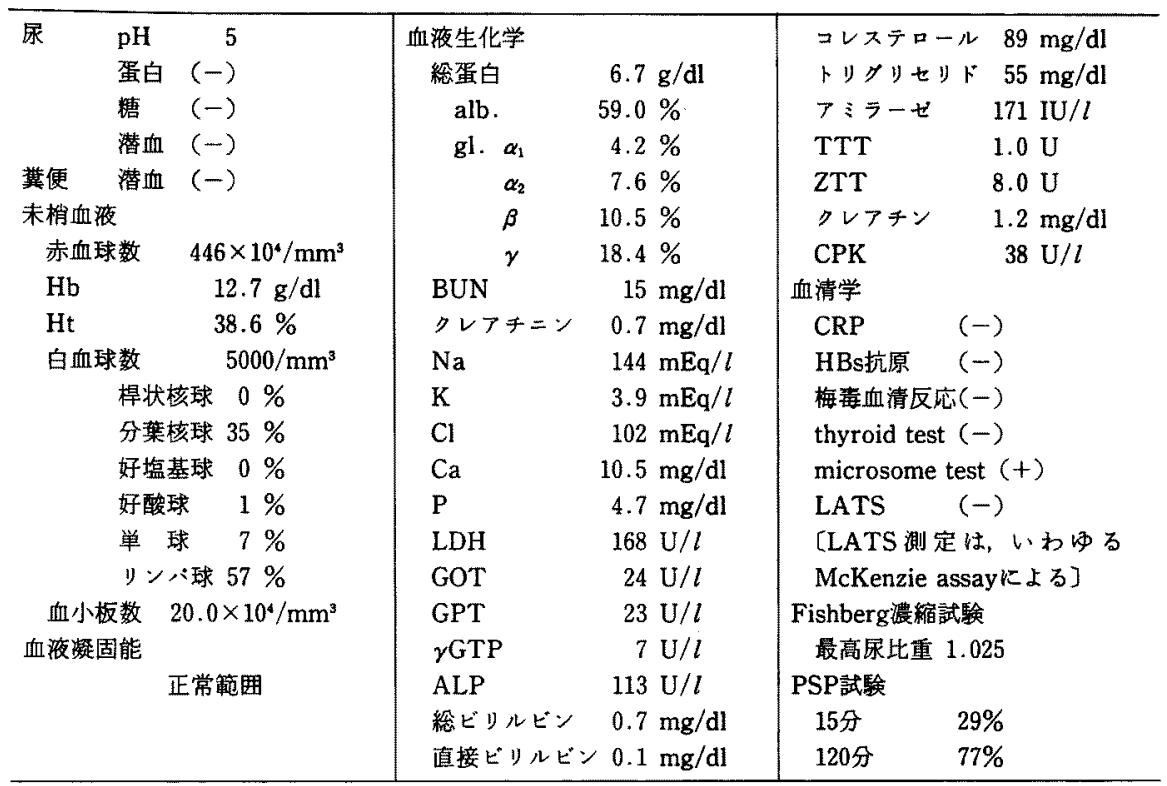

生じてきた. 1980年頃から手指振戦・動悸が生じ るようになり，12月15日，精查治療のため，東大 第二内科入入院した。

入院時現症：身長 $154.1 \mathrm{~cm}$, 体重 $54.4 \mathrm{~kg}$, 体 温 $36.8^{\circ} \mathrm{C}$, 脈拍 106 回/分, 整, 呼吸 20 回/分, 血生 136/36mmHg. 態度に落ちつきを欠き，感情は不 安定. 顔貌は先端巨大症様であり, 眉弓, 下顎の 突出, 鼻尖, 口唇の肥大を認めた。皮膚は湿潤し ていたが，色素沈着はなからた。視野狭窄・眼球 突出はなく，表在リンパ節は触知しなかつたが， び漫性ゴム様硬の甲状腺腫を触れた。甲状腺は左 右両葉腫大し, 圧痛, 結節, 血管雑音はなかつた。 胸部には異常なく, 腹部は平坦で肝・脾・堅は触 知されなかつた。四肢先端巨大がみられたが，手 指振戦以外, 神経学的に特に異常は認められなか つた。

検查所見：一般検査所見（表 1) では，尿 便に異常所見なく，負血も認められなかつた，血 清学的検查では, microsome test陽性であつた が, thyroid test, LATSは陰性であつた. 血液生 化学的検查では, albはやや低值で, 無機リン, Ca,
ALPは高值傾向を示した. ALPのisozymeはII IIIが高く骨型であつた，総コレステロールは低值 で,クレアチニンはやや高值であつたが，その他， 腎機能・肝機能は正常範囲であつた。

放射線学的検查では, 胸部 X 線像で CTR $46.6 \%$, 頭部単純 X線検査でトルコ鞍のballoning [前後径 $15 \mathrm{~mm} \cdot$ 深さ $14 \mathrm{~mm}$ ? double floor がみら れ，断層撮影では中央からやや左寄りの部分で前 下方への払大を示し，その部分の鞍底の骨皮質の 菲薄化がみられた。骨X線像では，指趾末節骨の 房状 カリフラワー状過骨形成があり, heal pad thicknessは22mm, Sesamoid indexは30であつ た。脳血管造影では, 左内頝動脈の cavernous portionは正常の屈曲を失い伸展した走行を示し， 毛細血管相ではmeningo-hypophyseal trunkから sella内に淡い均一なtumor stainを認めた。 また， cavenous sinusの造影は両側とも不良で，特に左 側ははとんど造影されなかつた。CT scanにて， トルコ鞍内に等吸収域のmassが認められ, 比較的 均等な造影効果を示した。また，冠状断でこの massは明らかに軽度の suprasellar extensionを 


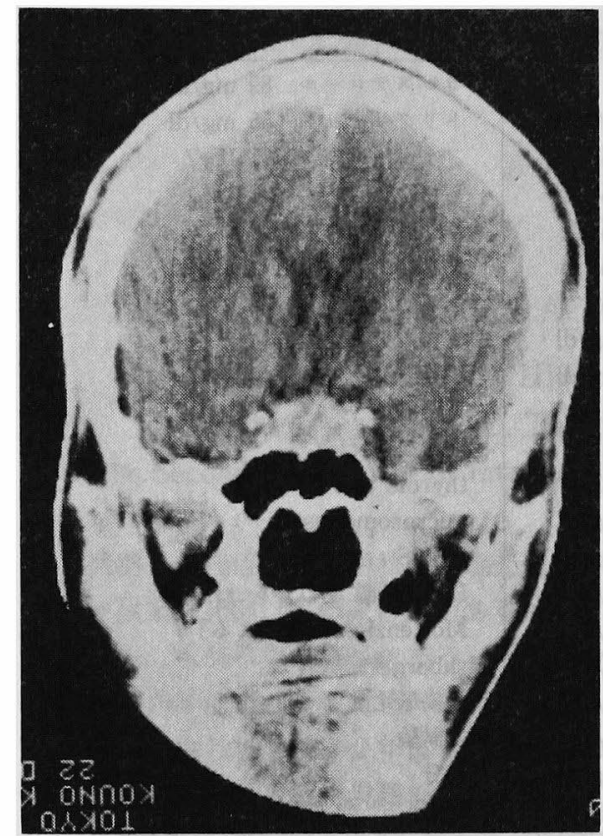

図1、頭部CT scan（造影後）一冠状断. トルコ鞍内 のmassは比較的均等な造影効果を示し, suprasellar extensionが認められた。

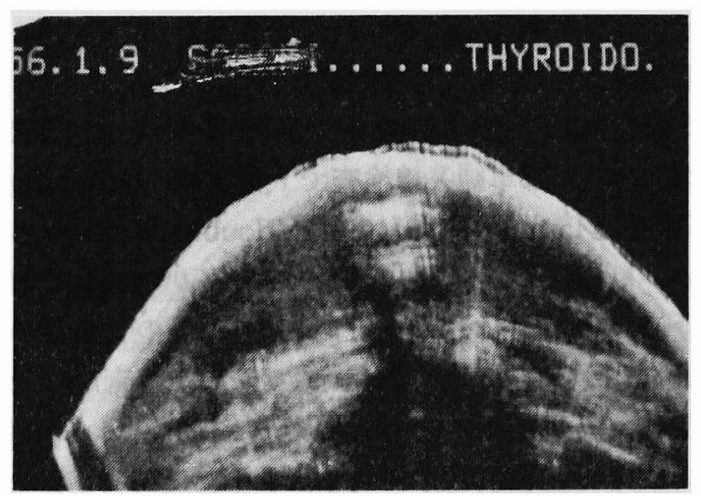

図2，甲状腺エコー. 両葉のび漫性腫大が認められる。

示していた(図 1 ). その他の画像検査では, 甲状 腺エコー（図 2 ），甲状腺シンチ（図 3）にて，両 葉のび漫性腫大が認められたが, 霊胞所見や結節 状の陰影欠損部はみられなかつた。 また，心電図 では，洞性頻脈（125/分）が認められた。

内分泌学的検査 (表 2 拈よ゙図 4 ) では, BMR,

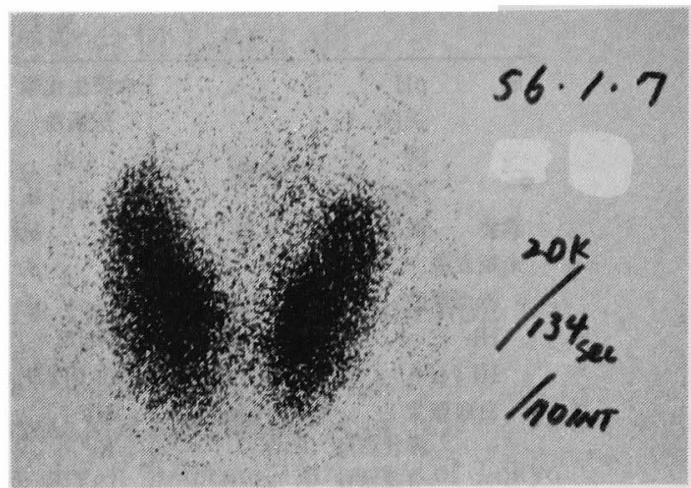

図 3，甲状腺シンチ.両葉のび漫性腫大が認められる。

表 2. 内分泌学的検査 (1) [入院時〕

\begin{tabular}{|c|c|}
\hline 甲状腺機能 & \multirow{3}{*}{$\begin{array}{ll}\text { 副甲状腺機能 } & \\
\text { PTH } & 780 \mathrm{pg} / \mathrm{ml} \\
\text { TRP\% } & 84.5 \%\end{array}$} \\
\hline$+50.0 \%$ & \\
\hline 131I攝取率 & \\
\hline triosorb試験 $46.3 \%$ & \multirow{3}{*}{$\begin{array}{l}\text { 下垂体副堅系機能 } \\
\text { rapid suppression試験 } \\
\text { cortisol }\end{array}$} \\
\hline $23.8 \mu \mathrm{g} / \mathrm{dl}$ & \\
\hline $397 \mathrm{ng} / \mathrm{dl}$ & \\
\hline 下垂体機能 & $1.25 \mu \mathrm{g} / \mathrm{dl}$ 以下 \\
\hline $2 \mu \mathrm{U} / \mathrm{ml}$ 以下 & \multirow{13}{*}{$\begin{array}{l}\text { rapid ACTH試験 } \\
\text { cortisol } \\
\text { (0分) } 11.9 \mu \mathrm{g} / \mathrm{dl} \\
(30 \text { 分) } 24.4 \mu \mathrm{g} / \mathrm{dl} \\
\text { (60分) } 28.5 \mu \mathrm{g} / \mathrm{dl} \\
\text { metyrapone試験 } \\
\text { 尿中17OHCS } \\
\text { (前日) } 19.1 \mathrm{mg} / \mathrm{d} \\
\text { (第1日) } 25.7 \mathrm{mg} / \mathrm{d} \\
\text { (第2日) } 22.4 \mathrm{mg} / \mathrm{d}\end{array}$} \\
\hline $16.1 \mathrm{mIU} / \mathrm{ml}$ & \\
\hline $4.6 \mathrm{mIU} / \mathrm{ml}$ & \\
\hline $50 \mathrm{pg} / \mathrm{ml}$ & \\
\hline $325.2 \mathrm{ng} / \mathrm{ml}$ & \\
\hline $4.7 \mathrm{ng} / \mathrm{ml}$ & \\
\hline 副腎機能 & \\
\hline $13.4 \mu \mathrm{g} / \mathrm{dl}$ & \\
\hline aldosterone $12.4 \mathrm{ng} / \mathrm{dl}$ & \\
\hline noradrenalin $206 \mathrm{pg} / \mathrm{ml}$ & \\
\hline $42 \mathrm{pg} / \mathrm{ml}$ & \\
\hline 尿中 $17 \mathrm{OHCS} 13.1 \mathrm{mg} / \mathrm{d}$ & \\
\hline 尿中17KS & \\
\hline
\end{tabular}

triosorb試験, $T_{3}, T_{4}$ および24時間 ${ }^{131} \mathrm{I}$-uptakeは いずれも高値を示し，TSHは低値を示した，安静 時のGHは極めて高値であり，一方PRLは低値を 示したが, LH, FSH, ACTH, aldosterone, adrenalin, noradrenalin, PTH, 尿中17-KS排泄量 はいずれも正常であつた。リン再吸収率(TRP\%) は正常下限であり, cortisol, 尿中170HCS排泄量 は僅かに高値を示した。 $100 \mathrm{~g}$ 経ロブドウ糖負荷試 験では, 血糖曲線はoxyhyperglycemiaを示し, 
a. 100 g経ロプドウ辖负荷試倹

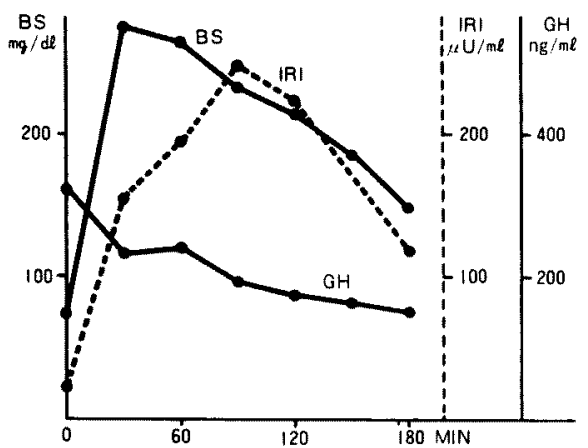

c. LH-RH試呀

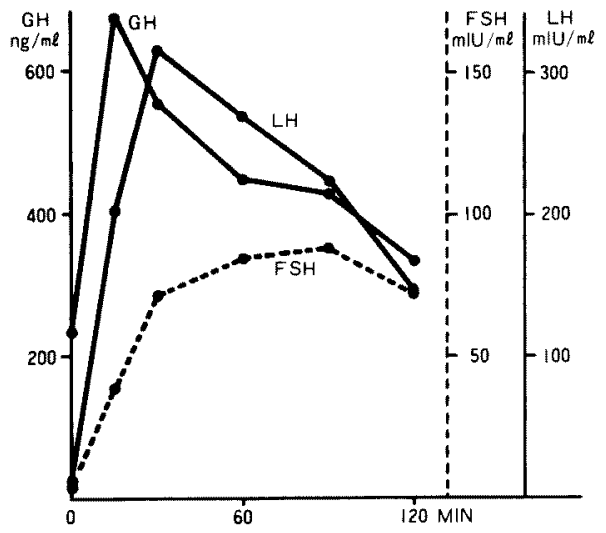

e. Bromocriptine 負荷試験

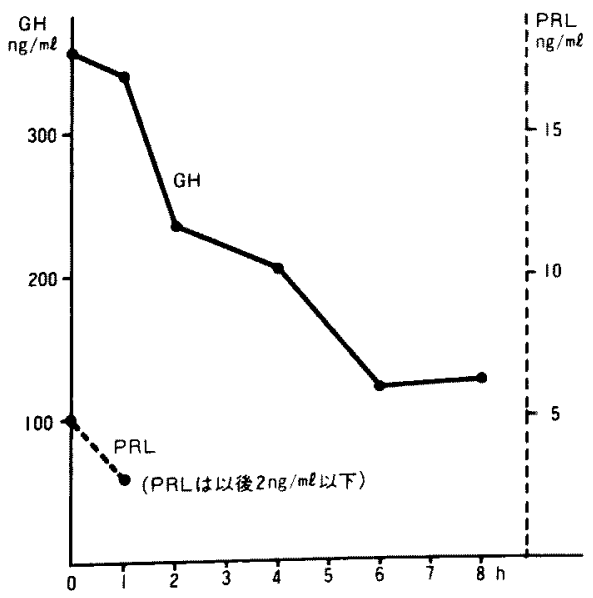

b. TRH試鵌

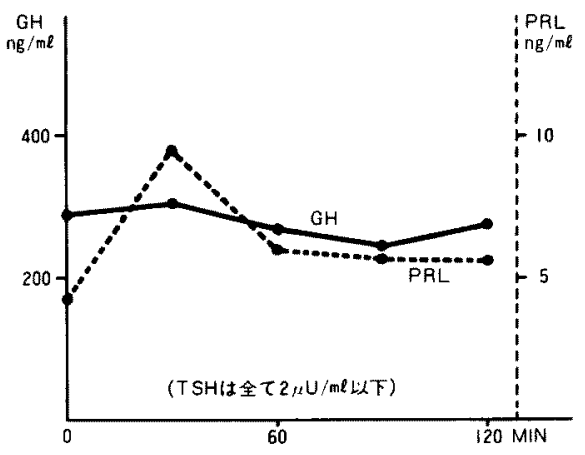

d. L-Dopa角荷試験

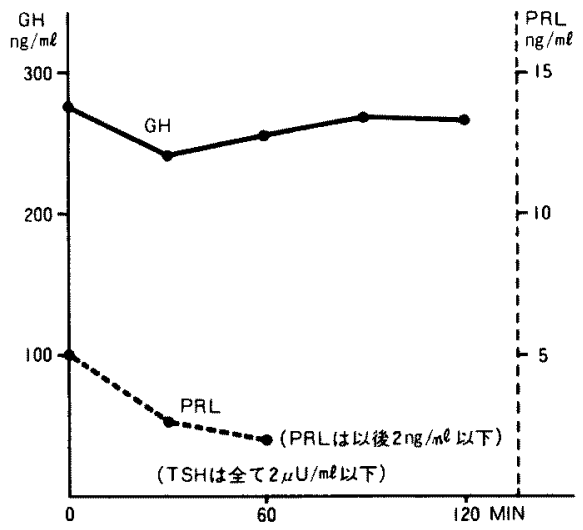

\section{f. Arginine 負荷試験}

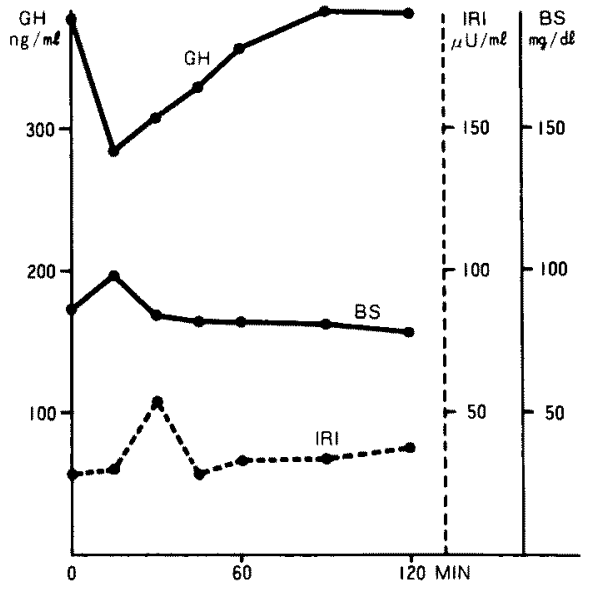

因 4，各種内分泌負荷試験（1）[入院時] 


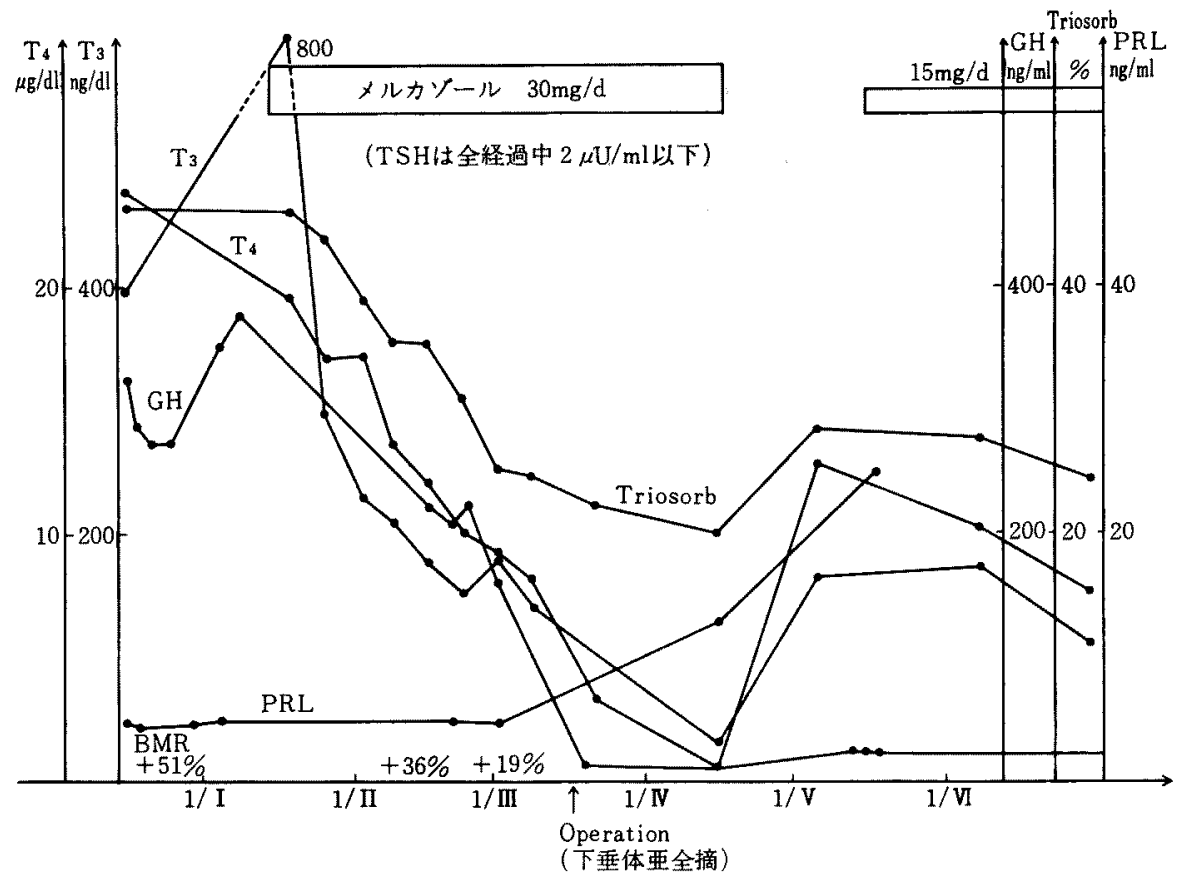

図 5，入院後経過（甲状腺機能とGH・PRLの推移）

insulinの分泌反応は遅延型であり，GHの分泌は 隇少を示した。 TRH $500 \mu \mathrm{g}$ 静注に対し，TSH GHは無反応であり，PRLの分泌増加が認められ た. LH-RH $100 \mu \mathrm{g}$ 静注に対しては，LH・FSHだ けでなく，GHす分泌増加を示した．L-dopa 500 mg程口投与に対し，GH・PRLの分必抑制が認め られたが, TSHは無反応であつた. bromocriptine $2.5 \mathrm{mg}$ 経口投与に対し, GH, PRLの分必抑制が認 められ, arginine $30 \mathrm{~g}$ 点滴投与にて, GHの分泌 促進は認められず，むしろ抑制され，insulinは30 分に頂値を示寸分泌増加が認められた。

入院後経過(図 5)：臨床症状および諸検査よ り，先端巨大症とBasedow病の合併が考えられ た. 甲状腺機能元進症に対しては, メルカゾール の投与を行ない， $\mathrm{T}_{4} \cdot \mathrm{T}_{3} \cdot$ triosorb試験は正常化 したが，TSHは依然として $2 \mu \mathrm{U} / \mathrm{ml}$ 以下であっ た。ま，BMRは次第に正常化していつた。下垂 体副腎系の検查(表 2)として, rapid suppression test ( 2 月 5 日)では, cortisolは $1.25 \mu \mathrm{g} / \mathrm{dl}$ 以下で
表 3.内分泌学的検查（2）【甲状腺機能正常化後]

\begin{tabular}{|c|c|c|}
\hline 甲状腺機能 & & 下垂体機能 \\
\hline BMR & $+19.0 \%$ & $2 \mu \mathrm{U} / \mathrm{ml}$ 以下 \\
\hline triosorb試騟 & $25.6 \%$ & $31 \mathrm{pg} / \mathrm{ml}$ \\
\hline$T_{4}$ & $9.3 \mu \mathrm{g} / \mathrm{dl}$ & $220.3 \mathrm{ng} / \mathrm{ml}$ \\
\hline$T_{3}$ & $181 \mathrm{ng} / \mathrm{dl}$ & $\begin{array}{l}\text { 副腎譏能 } \\
\quad \text { cortisol } \\
\text { aldosterone } 10.8 \mu \mathrm{ng} / \mathrm{dl} \\
10 . \mathrm{dl}\end{array}$ \\
\hline
\end{tabular}

正常反応であり, rapid ACTH test（2 月9 日） では, cortisolは正常の増加反応を示した。 また， metyrapone test ( 2 月12日) では, 尿中17OHCS の増加は認められたが，やや低反応であつた。

ほぼeuthyroidとなつた状態での内分泌学的検 查（表 3，図6）では，GHは依然として高值であ つたがやや減少傾向を示し，100g経ロブドウ糖負 荷試験, TRH試験, bromocriptine負荷試験では, 入院時之同様の反応が認められた. bromocriptineによるGHの分泌抑制が不十分であつた 
a. $100 \mathrm{~g}$ 経ロブドウ糖負荷試験

b. TRH試験

c. Bromocriptine 負荷試験
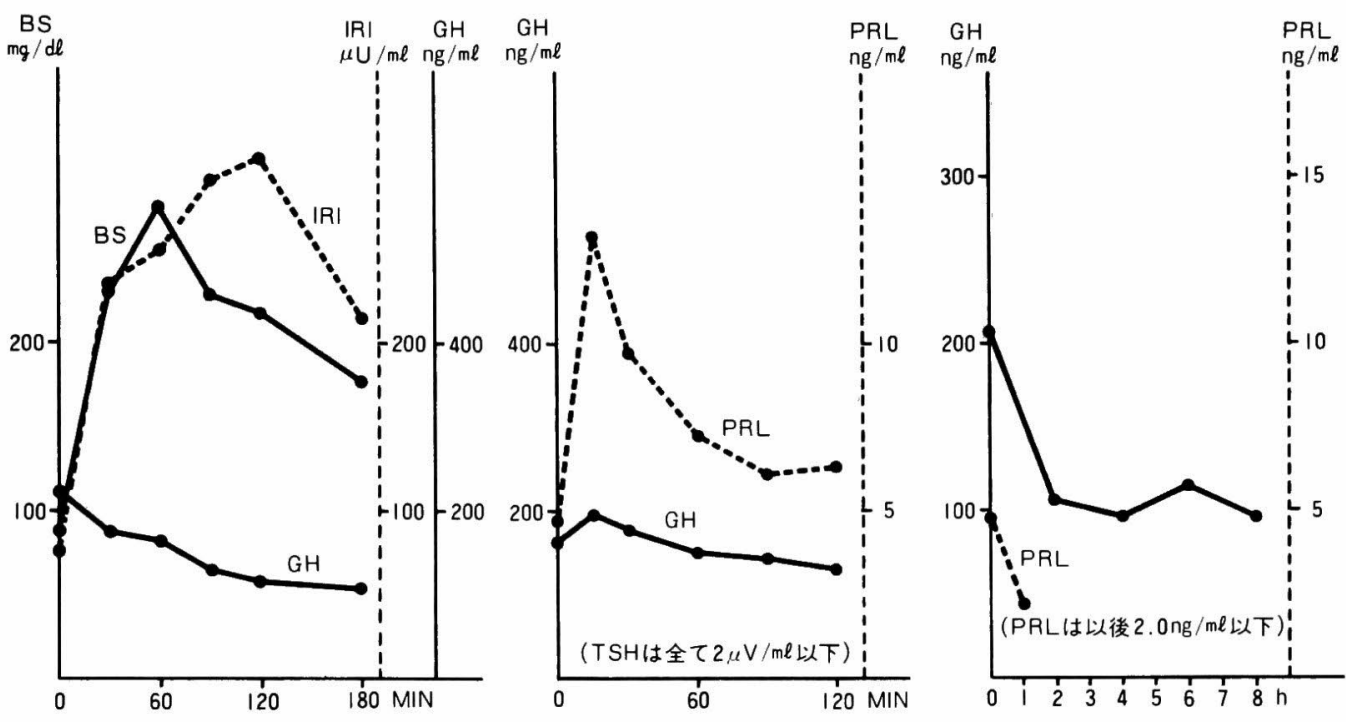

図 6. 各種内分泌負荷試験（2）〔甲状腺機能正常化後〕

ため，下垂体腺腫に対する手術を目的として，3 月12日，東大脳神経外科へ転科した。

手術所見（3 月17日）： Sublabial transsphenoidal approachにてトルコ鞍底を開放する と，軟かい黄灰白色のtumorの突出が認められた (図 7 ). tumorの進展は主に左側下方にみられ, 比 較的容易に亜全摘が可能であつた。 tumorの亜全 摘後，下垂体後葉と思われる組織と，圧排された 前葉と思われる組織が認められた。

病理組織学的所見：卵円形の核を持ち，好酸 性の胞体を有する細胞が， 5〜6個より成る acinusを形成する様に配列しており，一部に血管 の拡張した既存の下垂体組織が認められ（図 8), 好酸性下垂体腺腫と診断された。

術後経過： 術後 1 週頃より, 髄液鼻漏が出現 したため，4月 2 日，トルコ鞍の修復術が施行さ れた，その後，䯣膜炎や尿崩症が出現したが， 7 月頃より軽快し，9月より東大放射線科にて ${ }^{60} \mathrm{Co}$ 照射を総量 $50 \mathrm{~Gy}(2 \mathrm{~Gy} \times 5$ 回/週を 5 週間) 受け, 現在に至つている。な拉, 術後の続発性無月経に 対しては, 婦人科的治療が施行された。

術後の各種内分泌学的検査（表 4 -図 9)：手

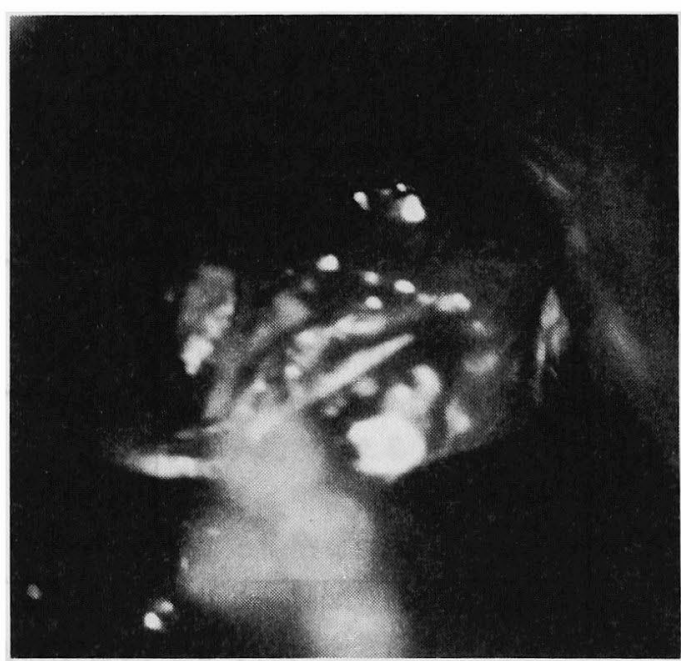

図 7 手術所見. トルコ鞍底を開放すると, 軟かい黄 灰白色のtumorの突出が認められた.

術 2 日後の $\mathrm{GH}$ は $13 \mathrm{ng} / \mathrm{ml}$ と急激に低下したが, そ の後はほぼ10～20ng $/ \mathrm{ml}$ 前後の值を示した．12月 より bromocriptineの投与も開始されたが著変は 認められなかつた．PRLは術後，4月16日には13 $\mathrm{ng} / \mathrm{ml}, 5$ 月 18 日には $25 \mathrm{ng} / \mathrm{ml}, 8$ 月 4 日には 36 


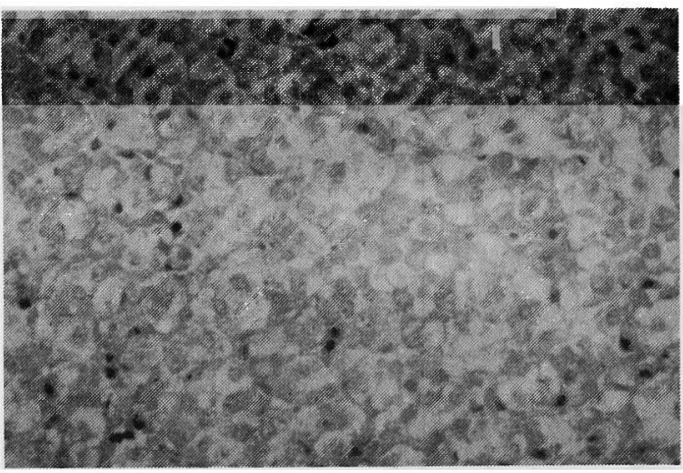

図 8. 病理組織学的所見. 卵円形の核と好酸性の胞体 を有する細胞が， 5 6 個より成るacinusを形成する 様に配列している（HE染色, $\times 200)$.
表 4. 内分泌学的検査（3）[下垂体腺腫亜全摘後]

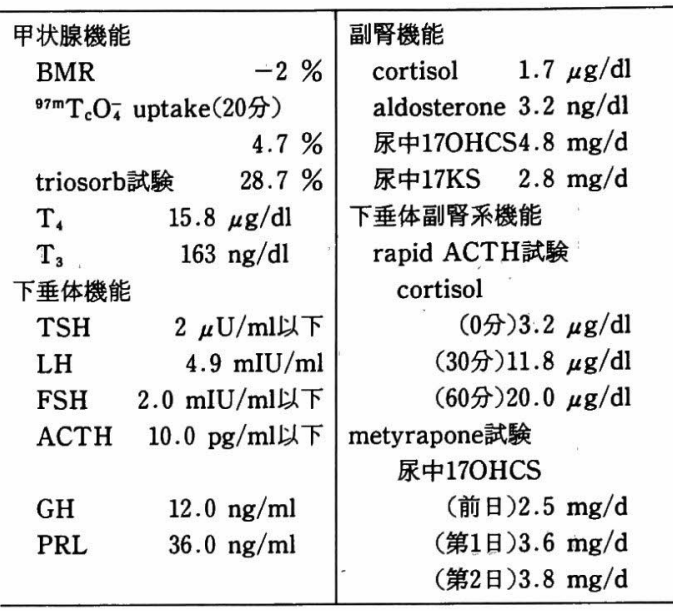

a. 100g経ロブドウ糖負荷試験

b. TRH試験

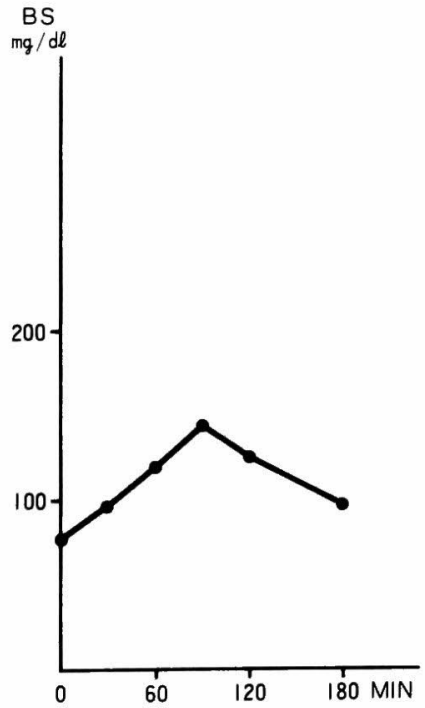

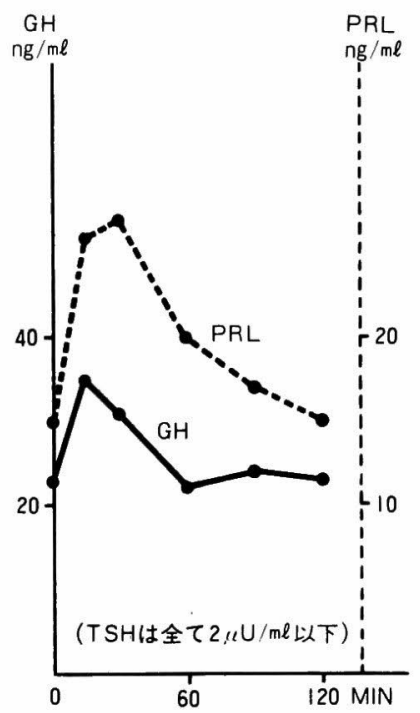

c. LH-RH試験

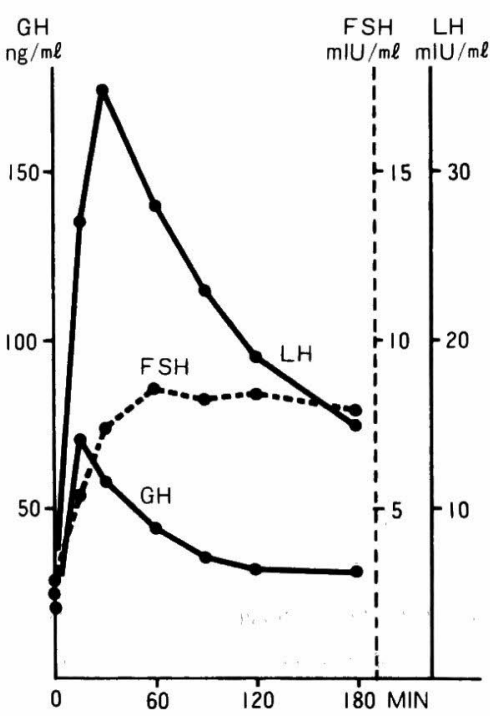

因 9，各種内分泌負荷試験（3）〔下垂体腺腫亜全摘後〕

$\mathrm{ng} / \mathrm{ml}$ と増加傾向を示した. 術後 1 カ月目に, 甲状 腺機能はhypothyroidismに傾いたため, メルカ ゾールを一時中止し，以後甲状腺機能を調べなが らメルカゾールの投与量を調節し，注添euthyroid

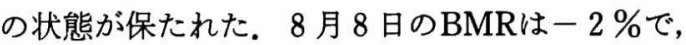
9 月 22 日の ${ }^{97 \mathrm{~m}} \mathrm{TcO}_{4}^{-}$uptake (20分) は $4.7 \%$ と正常 上限であつたが, TSHの増加はみられず，依然と
して $2 \mu \mathrm{U} / \mathrm{ml}$ 以下であつた。 また, $\mathrm{GH}$ が低下した 時点でも, 甲状腺腫の大きさには変化がみられな かつた１00g経ロブドウ糖試験では，ほぼ正常型 に近くなつていた. TRH試験, LH-RH試験は依然 として入院時と同様の反応を示した. rapid $\mathrm{ACTH}$ 試験では, cortisolの前値は $3.2 \mu \mathrm{g} / \mathrm{dl}$ と低 值であつたが，増加反応は良好であり，副腎皮質 
機能は正常と考兄られた。 metyrapone試験では, 尿中17OHCSの增加は認められたものの，前值の 2 倍以上の増加はみられず，下垂体ACTH分必予 備能の軽度の低下が考学られた。

\section{考案}

先端巨大症と甲状腺機能六進症との合併例は， 1927年にCushing and Davidoff ${ }^{2)}$ が報告して以来, 20 例以上が報告されている334). 先端巨大症では， GHの過剩による基礎代謝率え進や，全身的な臓 器肥大の一部分症状としての甲状腺腫が存在する ため，現在のようにホルモンの定量が簡単にでき なかつた時代においては，両疾患の合併の診断は 必ずしも容易ではなかつたと言える。1969年， Lamberg (4)は，TSH過剩による甲状腺機能六進 症を伴つた先端巨大症の症例を報告しており，そ の後，同様な症例を出村ら ${ }^{5)}$ ，余財 $5^{6)}$ が報告して いる. 今回の著者らの症例において，血中 $\mathrm{T}_{4}, \mathrm{~T}_{3}$, GHが高值であり，甲状腺機能六進症および先端 巨大症の存在は明らかであつた，本例の甲状腺機 能六進症に関しては，血中TSHが低值であり，

TRH試験に反応せず, thyroid test・LATSは陰性 であつたが，microsome testは陽性であり，甲状 腺シンチやェューでび漫性甲状腺腫が認められ，

Basedow病と診断するのが妥当であると考光ら れた。 また，内分泌負荷試験で，(1)ブドゥ糖負荷 により，GHが5ng/ml以下に抑制されないこと,(2) LH-RHに反応してGHの増加がみられたこと, (3) L-dopaやbromocriptine投与により GH分泌が抑 制されたことは，先端巨大症の猃断を支持する所 見である.

先端巨大症と，TSHの低値を示す一次性甲状腺 機能穴進症の合併例は, 著者らが調べた限りでは， 新実らの報告")と友常らの報告8)のみであつた，前 者はBasedow病で, 後者はtoxic multinodular goiterであり，本例は先端巨大症とBasedow病の 合併例としては，第 2 例目の報告である。

先端巨大症之甲状腺機能六進症を合併したもの のうち，TSHが高值を示す例では，下垂体腺腫か らGHとTSHの両者の分泌がなされていると考え られ, pituitary proton beam therapyまたは hypophysectomyが有効であつたとの報告があ る(4)9 11). その他, 甲状腺機能に関する詳細は不明 であるが，先端巨大症の $2.9 \%$ ( 5 例/172例) に血 清TSHが高值を示すとの報告もある12)

一方，本例のように，TSHが低值を示す一次性 甲状腺機能六進症と先端巨大症との合併例として は, 前述のよ5にBasedow 病中, toxic multinodular goiterが報告されている. 実験的に $\mathrm{GH}$ はラッの甲状腺腫形成作用をるつとの報告 があるが13), 友常らのtoxic multinodular goiter の例では, bromocriptine投与によつて血中GH值 が正常化した時点でも甲状腺腫の大きさに変化は みられず，かつ， ${ }^{131}$ 摄取率も低下しなかつた点か ら，GHの甲状腺組織に対する直接刺激作用は否 定的であつたとしている，先端巨大症の成因とし $\tau$, somatostatinやGRFの視床下部ホルモンの関 与が考えられてきて扣り ${ }^{14)}$ ，一方，GHの分泌抑制 因子であるsomatostatinはTRHに対するTSHの 分泌反応性を低下させると言われている15)，従つ て, もし先端巨大症がsomatostatinの欠乏によつ て発症してくるものと考えれば, somatostatinの 欠乏によりTRHに対するTSHの反応が増加し, 一時的にTSHの産生が過剩となり, 甲状腺を刺激 し続けた結果，最終的に甲状腺が自律性を獲得し たといら機序》る考光られるが，あくまでも推測 の域を出ない，以上より，現在のところ，先端巨 大症とBasedow病などの一次性甲状腺機能六進 症との合併は偶然と考兵る方が妥当であろう.

本例では，まず甲状腺機能元進症に対してメル カゾールによる治療を行ない, euthyroidの状態と なつてから下垂体腺尰の互全摘を施行した。この 間の各種内分泌学的検查に括いて, 本例の特徵と 考えられる点を以下に列挙すると，(1)甲状腺機能 六進症の改善とともに, GHむやや減少㑯向を示 したこと, (2)甲状腺機能の正常化後もTSHの増加 は認められず，TRH試験でもTSHは無反応であ つたこと, (3)下垂体腺腫垔全摘後, GHは急速に減 少したが，正常域には至らず，その後放射線照射 やbromocriptineの投与が必要となつたこと, (4) GHが減少するとともに，PRLは增加傾向を示し 
たこと, (5)ACTH分泌予備能の低下が疑われたこ と，(6)術後，続発性無月経をきたしたこと，など である．PRL増加に関しては，手術により下垂体 茎が障害され，二次的にPRL release-inhibiting factorを低下させた可能性が考えられ，ACTH分 泌予備能の低下については，下垂体腺腫そのもの や，手術の影響が考学られた。

新実らの例7)では，甲状腺機能六進症の治療に より，末梢甲状腺ホルモンが正常〜低值となつた 状態でのGHは増加傾向を示し，TRHに対する GHの反応性も増大しており, Basedow病の合併 により，先端巨大症の活動性の一部が抑制された と考学ている。本例では，GHは甲状腺機能六進症 の治療に伴い減少傾向を示し，この点新実らの仮 説に合致しない，甲状腺機能低下症においては視 床下部一下垂体機能の低下があるため，GHは一般 に減少するとされて扣り ${ }^{16)}$ ，このことから演繹す ると，本例に和いては，甲状腺機能六進により， 視床下部一下垂体機能も元進し, GHの増加を助長 していた，とも推測できる。ただし，Basedow病 におけるGHは正常範囲内であるとの報告が多 く,甲状腺機能六進は必ずしも視床下部一下垂体機 能え進を惹起しないようである.甲状腺機能正常 化後もTSHが低値を示し，TRH試験でもTSHは 無反応であつた点に関しては，下垂体腺腫の影響 によるとる考觉られるが，Basedow病のなかには このよらな例もあり ${ }^{17)}$, 原因は明らかではない。こ の現象は血中甲状腺ホルモン值のみでは説明でき ず, 下垂体内の $\mathrm{T}_{4}, \mathrm{~T}_{3}$ の高值やnegative feedback のsetting pointの異常などの可能性が考えられて いる。な招，TRH試験におけるTSHの低反応は， euthyroidの先端巨大症においても認められるこ とが報告されている18).

以上より，本例に打ける先端巨大症と Basedow 病の合併に関しては，Basedow病がGH增加を助 長した可能性は否定できなかつたが，両疾患の因 果関係を積極的に示咬する所見は認められず，先 端巨大症とBasedow病の合併は偶然であるとす るのが妥当であろらと考えられた。

\section{結語}

活動性の先端巨大症とBasedow病を合併した 症例を報告した，両疾患の合併に関して，本症例 に扮ける視床下部一下垂体のホルモン分泌動態を 中心に，考察を加えた。

\section{文献}

1) Daughaday WH: The adenohypophysis. Textbook of endocrinology (5th Edition), ed by Williams RH, WB Saunders Co, Philadelphia, 1974, p31.

2) Cushing $\mathrm{H}$ and Davidoff LM: Studies in acromegaly. Arch Intern Med 39: 673, 1927.

3) Roth J, et al: Acromegaly and other disorders of growth hormone secretion. Ann Intern Med $66: 760,1967$.

4) Lamberg BA, et al: Chromophobe pituitary adenoma with acromegaly and $\mathrm{TSH}$-induced hyperthyroidism associated with parathyroid adenoma. Acta Endocrinologica 60 : 157, 1969.

5）出村黎子，他：TSH過剩分泌に上る甲状腺機能六 進症を伴つたAcromegaly．医学のあゆみ 84 ： 637, 1973.

6）余財伸一，他：甲状腺機能六進症扣上び糖尿病を 合併した末端肥大症の 1 例. 日内会誌 $60: 769$, 1971.

7）新実光朗，他：末端肥大症と甲状腺機能六進症を 合併した一症例. 臨床内分泌之代謝 $1: 21,1978$.

8）友常靖子，他：巨大な甲状腺腫を伴つたアクロ大 ガリーの1例. ホルモンと臨床 $27: 27 ， 1979$.

9) Hamilton CR Jr, et al : Acromegaly and toxic goiter. Cure of the hyperthyroidism and acromegaly by proton-beam patial hypo. physectomy. J Clin Endocrinol Metab 35 : 659, 1972.

10) Sandler R: Recurrent hyperthyroidism in an acromegalic patient previously treated with proton beam irradiation: Graves' disease as probable etiology based on follow-up observations. J Clin Endocrinol and Metab 42: 163, 1976.

11) Lamberg BA, et al: Thyroid function in acromegaly before and after transsphenoidal hypophysectomy followed by cryoapplication. Acta Endocrinol 82: 254, 1976.

12）中川光二：新内分泌データブック，ホルモンと臨 床, 增刊号, 上巻: 76, 1977 .

13) Ching $\mathrm{MCH}$, et al: Role of growth hormone in the enhancement of the propylthiouracil-induced goitrogenesis by small doses of thyroix- 
ine. Acta Endocrinol $79: 238,1975$.

14) Dhariwal APS, et al: Purification of growth hormone-releasing factor. Endocrinology 77 : $932,1965$.

15) Vale W, et al: Effects of somatostatin on the secretion of thyrotropin and prolactin. Endocrinology $95: 968,1974$.

16) Minozzi $M$, et al: Somatotrophic and corticotrophic functins in primary hypothyoidism, before and after thyroxine treatment. Acta Endocrinol $74: 483,1973$.

17) Azukizawa $M$, et al: Relation between pituitary responsiveness to thyrotropin releasing hormone and serum thyroid hormones in hyperthyroidism. Endocrinol Jap $21: 335,1974$.

18) Lamberg BA, et al: Conventional pituitary irradiation in acromegaly. Acta Endocrinol 82 : $267,1976$. 